\title{
Introduction to the Arctic Oil and Gas Research Centre
}

\section{Rachael Lorna Johnstone ${ }^{\star}$,}

Professor of Law, Ilisimatusarfik, University of Greenland, Nuuk, Greenland

Anne Merrild Hansen,

Professor of Social Science, Ilisimatusarfik, University of Greenland, Nuuk, Greenland

The Research Centre for Arctic Oil and Gas was opened at Ilisimatusarfik (the University of Greenland) on 16 March 2016. The directors of the Centre are Professor Anne Merrild Hansen and Professor Rachael Lorna Johnstone. The Centre operates within the Institute of Social Sciences, Economics and Journalism at Ilisimatusarfik.

The Centre will draw together local community members, government representatives, oil and gas companies, NGOs, and academics to examine the social and economic impacts of oil and gas activities in the Arctic with an emphasis on Greenland. The Centre is based at Ilimmarfik in Nuuk, but the directors will travel around Greenland to meet with different communities, holding meetings with invited stakeholders as well as open fora to ensure that all concerned persons can present their views and hear about the Centre's work.

A Greenland-based network of experts will be established, tasked with researching economic and social implications of Arctic oil and gas activities and sharing their results. Researchers will be sought from around the Arctic and beyond in the fields of economics, political science, social anthropology, law, international relations, and critical geography. The network will also reach out to non-academic stakeholders and seek their contributions to the research activities.

The Centre will organise and host symposia on Arctic oil and gas, open to the public, to present findings. The directors and members of the network will participate in international conferences to share their research and promote the Centre more widely. Dissemination of research findings will be tailored to meet the various needs of different groups, with academic publications complemented with popular science briefing notes in Greenlandic, Danish and English, and oral presentations tailored to non-specialist audiences alongside academic conference presentations. Working

^Correspondence to: Rachael Lorna Johnstone, Arctic Oil and Gas Research Centre, Institute of Social Science, Economics \& Journalism, Ilisimatusarfik, University of Greenland, Manutooq 1, 3905 Nuussuaq, Greenland. Email: ralo@uni.gl 


\section{R. L. Fohnstone and A. M. Hansen}

papers and briefing notes will be published on an open-access basis on the Centre's website to facilitate the widest possible access.

The Centre aims to contribute to the academic development of the next generation of Greenlandic thinkers and leaders. The directors will supervise doctoral and master's students in relevant fields and teach courses at Ilisimatusarfik on sociology, international law, and oil and gas governance. They will also be involved in curriculum development at Ilisimatusarfik.

The directors' salaries are initially funded through a 3-year grant from the Mineral Licence and Safety Authority (MLSA) which is administered through Ilisimatusarfik. Companies holding exclusive licences for the exploration and exploitation of hydrocarbons in Greenland make payments to the MLSA in accordance with their respective license agreements regarding capacity building.

The work of the directors and researchers is entirely independent of the MLSA and the oil companies. The MLSA and oil companies do not direct the research agenda or approve any research findings. The researchers are also in the process of seeking additional external funding from competitive grant bodies to facilitate expansion of the Centre's activities.

\section{Website}

http://uk.uni.gl/research/arctic-oil-and-gas-research-centre.aspx (EN) http://www.uni.gl/ilisimatuutut-misissuinerit/ilisimatusarfik-issittumi-uuliamik-gasimillusammisalik.aspx (GL)

http://da.uni.gl/forskning/forskningscentret-for-arktisk-olie-og-gas.aspx (DK)

\section{Biographies}

Anne Merrild Hansen is Professor of Social Science, Arctic Oil and Gas Studies at Ilisimatusarfik, Director of the Arctic Oil and Gas Research Centre, Associate Professor in Environmental Assessment and the Arctic at Aalborg University, Denmark, and a Fulbright Arctic Initiative scholar 2015-2016 with University of Alaska, Fairbanks.

Rachael Lorna Johnstone is Professor of Law, Arctic Oil and Gas Studies at Ilisimatusarfik, Director of the Arctic Oil and Gas Research Centre, and Professor of Law at the University of Akureyri, Iceland. 